\title{
INTENSITY OF OXIDATIVE STRESS AND ACTIVITY OF ANGIOTENSIN CONVERTING ENZYME IN BLOOD OF PATIENTS WITH UNCOMPLICATED PYELONEPHRITIS
}

\author{
L. V. KOROL, L. Ya. MYGAL, N. M. STEPANOVA \\ State Institution Institute of Nephrology, National Academy \\ of Medical Sciences of Ukraine, Kyiv; \\ e-mail: lesyakorol@meta.ua
}

The purpose of this work was to study the correlation between oxidative stress (OS) marker and angiotensin converting enzyme (ACE) activity in patients with chronic kidney disease stages I-II (uncomplicated pyelonephritis). The 32 patients with uncomplicated pyelonephritis and 30 healthy volunteers (women, age - 18-40 years) were involved in this study. The content of thiobarbituric acid reactive products, protein carbonyl groups, ceruloplasmin, transferrin, the SH-groups, the total peroxidase activity of erythrocytes were determined by colorimetric method. OS index was calculated. To evaluate the functional state of the renal parenchyma the activity of tubular lysosome enzymes a total $\beta$ - $N$-acetylhexosaminidase and $\beta$-galactosidase were determined in urine. The correlation analysis between activities of ACE and OS was performed. The ACE increased activity was shown on the background of violations of pro/antioxidant balance. The correlation analysis confirmed the presence of a moderate relationship between ACE activity and the majority of the studied parameters. Thus, an increase in ACE activity, intensification of oxidative processes, decrease of antioxidant defense contributes to the development of local OS, as well as the development of dysfunction in renal tubular system (according to the increased activity of renal specific enzymes in the urine).

Key words: oxidative stress, angiotensin converting enzyme, uncomplicated pyelonephritis, $\beta$ - $N$ acetylhexosaminidase, $\beta$-galactosidase.

$\mathrm{R}$ ecently much attention has been paid to the study of renal function in regulating the homeostasis in the assessment of the role of callicrein-kinin, the renin-angiotensin-aldosterone system and prostaglandins, their role in the development of oxidative stress (OS) in chronic kidney disease (CKD) [1, 2]. It is well known that the activation of the callicrein-kinin and renin-angiotensinaldosterone systems causes the increased secretion of vasoactive peptides, including angiotensin II, bradykinin, renin, and promotes the activation of a wide spectrum of neurohormonal, metabolic, inflammatory and procoagulation reactions, that leads to the increase of reactive oxygen species (ROS) [3-6].

The pathogenetic role of angiotensin-II was proved in the development of nephropathy and hypertension. It plays a direct role in the vasopressor effects, promotes intraglomerular hypertension and is one of the key molecules that trigger oxidative stress and inflammation in the vascular wall. One of the effects of angiotensin II is the activation of nuclear transcription factors that stimulates the expression of cytokines, chemokines, nitric oxide (NO), cyclooxygenase-2, adhesion molecules. Endothelial damage primarily affects the production of NO-synthase (NOS) [1, 7].

Angiotensin-II is involved in the inflammatory reactions and enhances the proliferation of cells, including renal glomerular mesangial cells, contributing to the progression of fibrosis. Another important factor of disorder of renin-angiotensin system is transforming growth factor $\beta$ (TGF $\beta$ ), which stimulates synthesis of the various components of the extracellular matrix degradation and blocks protease inhibitors. In addition, TGF- $\beta$ stimulates the production of endothelin-1 - a powerful vasoconstric-

(C) 2017 Korol L. V. et al. This is an open-access article distributed under the terms of the Creative Commons Attribution License, which permits unrestricted use, distribution, and reproduction in any medium, provided the original author and source are credited. 
tor, which plays a key role in the control of vascular tone. Also TGF inhibits NO production in the endothelium [8-10].

Angiotensin converting enzyme (ACE, EC 3.4.15.1) is a central component of the renin-angiotensin system, which controls blood pressure by regulating the volume of fluids in the body. Therefore, ACE indirectly increases blood pressure by making the blood vessels to constrict. ACE inhibitors have vasoprotective, anti-proliferative, antisclerotic properties and vasodilating effects. That explains their effects on the endothelium. In addition, ACE inhibitors prevent the breakdown of bradykinin, which is a powerful stimulant of NO release [4-6].

The role of OS in the pathogenesis of pyelonephritis is actively studied today. Development of OS in patients with pyelonephritis is accompanied by the accumulation of high concentrations peroxidation products in the blood and tissues. However, the relationship markers of OS and the activity of ACE in patients with pyelonephritis remains poorly understood.

The preset work studies the relationship between OS markers and the activity of ACE in the blood of patients with uncomplicated pyelonephritis. At this stage we analyzed the results of determination of ACE activity and OS markers in 32 patients with uncomplicated pyelonephritis.

\section{Materials and Methods}

The venous blood and urine samples were taken from 32 patients (women, age - 18-40 years) with CKD I-II stage (uncomplicated pyelonephritis). The control group consisted of 30 healthy women of the same age. All participants gave informed consent for the study prior to the procedure of obtaining their blood and urine. The study protocol (No 7 30.08.2016) was approved by the Commission on Bioethics of SI Institution of Nephrology NAMS.

Preparation of biological material. Blood from the cubital vein without anticoagulant were centrifuged for $15 \mathrm{~min}$ at $1500 \mathrm{~g}$ and treated with serum. Preparation of red blood cells: red cell suspensions for blood taken with an anticoagulant (heparin) and centrifuged for $10 \mathrm{~min}$ at $3000 \mathrm{~g}$. Red cell mass was washed three times with isotonic sodium chloride and centrifuged for $10 \mathrm{~min}$ at $3000 \mathrm{~g}$.

There are reagents used in this study: 2,4-dinitrophenylhydrazine, 1,2-phenylenediamine dihydrochloride, Indigo Carmine, ammonium
iron(III) citrate, N-3-(2-Furyl)-acryloyl-phenylalanyl-glicyl-glycine, 4-nitrophenyl-2-acetamide-2deoxy- $\beta$-D-glycopyranoside, $p$-nitrophenyl- $\beta$-Dgalactopyranoside (Sigma-Aldrich, USA); transferrin (Fluka); urea, sodium fluoride, ethylenediaminetetraacetic acid (EDTA), sodium acetic, potassium iodide, tris, trichloroacetic and thiobarbituric acid (Merck, Germany).

ACE activity was determined with spectrophotometric method, using as substrate- $\mathrm{N}-[3$-(2-Furyl) acryloyl-phenylalanyl-glicyl-glycine [11]. The procedure of analysis: $0.02 \mathrm{ml}$ of serum was taken in the experimental and control samples. The $0.1 \mathrm{ml} 1 \mathrm{mM}$ $\mathrm{N}$-[3-(2-Furyl) acryloyl-phenylalanyl-glicyl-glycine was added to experimental samples, and $0.1 \mathrm{ml}$ of EDTA - to control samples. Samples were incubated at $37^{\circ} \mathrm{C}$ for $30 \mathrm{~min}$. Then $0.1 \mathrm{ml}$ of $20 \mathrm{mM}$ solution EDTA was added to the experimental sample, and $0.1 \mathrm{ml}$ of $1 \mathrm{mM} \mathrm{N}$-[3-(2-Furyl) acryloyl-phenylalanyl-glicyl-glycine - to the control sample. Then $2.3 \mathrm{ml}$ of $0.05 \mathrm{M}$ Tris buffer $\mathrm{pH} 8.3$ with $300 \mathrm{mM}$ of sodium chloride was added to both samples. The absorbance was (measured) at $334 \mathrm{~nm}$. The results are expressed in $\mu \mathrm{kat} / \mathrm{l}$.

The content of the protein carbonyl groups (PCG) in serum blood was determined by reaction of the oxidized amino acid residues of $0.1 \mathrm{M} 2,4$-dinitro phenyl-hydrazine [12]. The $0.1 \mathrm{ml}$ of serum was added to $1 \mathrm{ml}$ of $20 \%$ solution of trichloroacetic acid and centrifuged samples for $15 \mathrm{~min}$ at $3000 \mathrm{~g}$. To protein precipitates were added $0.1 \mathrm{M}$ solution of 2,4-dinitro phenyl-hydrazine and incubated within 1 h. The samples were centrifuged for $15 \mathrm{~min}$ at 3000 g. The protein precipitates were treated with a mixture of ethyl acetate-ethanol $(1: 1)$ and dissolved in $2 \mathrm{ml}$ of $8 \mathrm{M}$ aqueous urea solution. The absorbance was (measured) at $363 \mathrm{~nm}$. PCG concentration was expressed as $\mu \mathrm{mol} / \mathrm{l}$.

Lipid peroxidation was characterized by formation of thiobarbituric acid reactive products (TBARP) following the procedure of $[12,13]$. The $0.1 \mathrm{ml}$ serum or red blood cells were added to $1.5 \mathrm{ml}$ 0.025 M Tris-buffer with potassium chloride ( $\mathrm{pH}$ 7.4) and incubated for 30 minutes at $37^{\circ} \mathrm{C}$. To samples were added $1 \mathrm{ml} 17 \%$ solution of trichloroacetic acid and centrifuged for $20 \mathrm{~min}$ at $3000 \mathrm{~g}$. Supernatants $(2 \mathrm{ml})$ were added to $1 \mathrm{ml}$ of $0.8 \%$ solution of thiobarbituric acid and heated for $10 \mathrm{~min}$ at $100{ }^{\circ} \mathrm{C}$. The absorbance was (measured) at $532 \mathrm{~nm}$ and was calculated using a molar extinction coefficient of $1.56 \times 10^{5} \mathrm{M}^{-1} \mathrm{~cm}^{-1}$. TBARS concentration was expressed as $\mu \mathrm{mol} / \mathrm{l}$. 
Ceruloplasmin (CP) concentration in the blood serum was determined according to the process [13]. The experienced samples: $0.05 \mathrm{ml}$ of serum was added to $4 \mathrm{ml} 0.4 \mathrm{M}$ of acetic buffer solution (pH 5.5) and $0.5 \mathrm{ml} 0.5 \%$ aqueous solution of 1,2-phenylenediamine dihydrochloride. The control sample ( $0.05 \mathrm{ml}$ serum) was added to $1 \mathrm{ml}$ of $3 \%$ solution of sodium fluoride, $4 \mathrm{ml}$ of acetate buffer and 0.5 $\mathrm{ml} 0.5 \%$ aqueous solution of 1,2-phenylenediamine dihydrochloride. Samples were incubated for 1 hour at $37^{\circ} \mathrm{C}$. To experiment sample was added $1 \mathrm{ml}$ of $3 \%$ solution of sodium fluoride. The absorbance was measured at $530 \mathrm{~nm}$ [13]. CP concentration was expressed as $\mathrm{g} / \mathrm{l}$.

The content of transferrin (TR) in serum samples was determined following the procedure [13]. The $0.2 \mathrm{ml}$ of serum was added to $2 \mathrm{ml}$ of $0.2 \%$ solution of ammonium-iron(III)-citrate (pH 5.5-5.8). The absorbance was measured at $440 \mathrm{~nm}$ after the first minute and thirtieth minute. TR content was calculated as the difference between the absorbance of the solution for $30 \mathrm{~min}$. The standard solutions of TR were used for control. The result is expressed in $\mathrm{g} / \mathrm{l}$.

The total peroxidase activity (TPAe) in erythrocyte was determined for the procedure [13]. The $0.5 \mathrm{ml}$ hemolysate of erythrocyte $(1: 1000), 1 \mathrm{ml}$ of $0.2 \mathrm{M}$ acetate buffer (pH 4.9), $1 \mathrm{ml} 0.05 \mathrm{mM}$ Indigo Carmine solution was incubated at $30^{\circ} \mathrm{C}$ for $5 \mathrm{~min}$. The reaction start up adding $0.5 \mathrm{ml} 0.03 \mathrm{M}$ solution hydrogen peroxide to the test samples. The control samples were added $0.5 \mathrm{ml}$ of distilled water. The reaction was stopped $2 \mathrm{~min}$ after the addition of $3 \mathrm{ml}$ of $20 \%$ sulfuric acid. The absorbance was measured at $670 \mathrm{~nm}$. TPAe concentration was expressed as $\mu \mathrm{kat} / \mathrm{g} \mathrm{Hb}$.

The level SH-groups in the serum blood were determined according to procedure [13]. The $0.05 \mathrm{ml}$ of serum was dissolved to $0.5 \mathrm{ml}$ with distilled water and added $0.5 \mathrm{ml}$ of $6 \mathrm{M}$ potassium iodide solution, 2 drops of $5 \%$ starch solution and $1.8 \mathrm{ml}$ of $0.1 \mathrm{M}$ phosphate buffer ( $\mathrm{pH}$ 7.6). The absorbance was measured at $500 \mathrm{~nm}$ before and after the application of $0.3 \mathrm{ml} 0.001 \mathrm{~N}$ of iodine solution. The level of SH-groups concentration was expressed as $\mathrm{mmol} / \mathrm{l}$.

The OS index (OSI) was calculated by the formula described previously [13]. The method includes determination of content of TBARP, CP, TR and SHgroups in the blood serum for calculation of OSI by the formula:

$$
\begin{aligned}
& \text { OSI = (TBARPp/TBARPc)/[(CPp/CPc + } \\
& + \text { TRp/TRc + SHp/SHc): 3], }
\end{aligned}
$$

where TBARPp - the content of TBARP of serum of the patient; TBARPc - TBARP content in the control group (mean value); $\mathrm{CPp}-\mathrm{CP}$ in the blood serum of the patient; $\mathrm{CPc}$ - the content of the $\mathrm{CP}$ in the control group (mean value); TRp - the content of TR in the blood serum of the patient; TRc - TR content in the control group (mean value); SHp - SH-groups content in the blood serum of the patient; $\mathrm{SHc}-\mathrm{SH}$ groups content in the control group (average value).

The level of arginine concentration was determined according to procedure [14]. The procedure of analysis: $0.2 \mathrm{ml}$ of serum, $0.7 \mathrm{ml}$ of $0.1 \mathrm{M}$ phosphate buffer ( $\mathrm{pH} \mathrm{7.4)}$ ) and $0.1 \mathrm{ml}$ of $30 \%$ solution of trichloroacetic acid were taken in the sample and centrifuged for $15 \mathrm{~min}$ at $3000 \mathrm{~g}$. Water $(0.5 \mathrm{ml})$ and the reaction mixture were added to $0.5 \mathrm{ml}$ of the supernatant. The reaction mixture contained $2 \mathrm{M}$ solution of $\mathrm{NaOH}, 0.02 \%$ solution of 8-hydroxyquinoline, $0.0066 \%$ sodium hypobromite, $40 \%$ solution of urea. The absorbance was measured at $490 \mathrm{~nm}$. The level of arginine concentration was calculated using standard solutions and expressed as $\mathrm{mmol} / \mathrm{l}$.

To evaluate the functional state of the renal parenchyma we used the enzymes activity of lysosomal origin - total $\beta-\mathrm{N}$ - acetylhexosaminidase (EC 3.2.1.52, NAG) and $\beta$-galactosidase (EC 3.2.1.23, $\beta$-Gal) in (5 ml), eight-hour morning portion of urine without preservatives. The NAG activity was determined by reaction with 4-nitrophenyl-2-acetamide2 deoxy- $\beta$-D-glycopyranoside in the acidic medium with the formation of p-nitrophenol [15]. The NAG activity was determined according to procedure [15]. The procedure of analysis: $0.2 \mathrm{ml}$ of urine, $0.3 \mathrm{ml}$ of $0.1 \mathrm{M}$ citrate buffer ( $\mathrm{pH} 4.15$ ), the $0.2 \mathrm{ml}$ of $10 \mathrm{mM}$ 4-nitrophenyl-2-acetamide-2deoxy- $\beta$-Dglycopyranoside was added to experimental samples and incubated at $37^{\circ} \mathrm{C}$ for $1 \mathrm{~h}$. The reaction was stopped by $0.8 \mathrm{ml}$ of $0.1 \mathrm{M}$ soda solution. In the control the sample substrate is added after stopping the enzyme reaction. The absorbance was measured at $400 \mathrm{~nm}$ vs control samples. The NAG activity in urine was calculated using standard solutions of p-nitrophenol and expressed as $\mu \mathrm{mol} / \mathrm{h} / \mathrm{mmol}$ creatinine in urine. The $\beta$-Gal activity was determined according to procedure [15]. The procedure of analysis: $0.2 \mathrm{ml}$ of urine, $0.3 \mathrm{ml}$ of $0.1 \mathrm{M}$ citrate buffer ( $\mathrm{pH} 4.15$ ), the $0.2 \mathrm{ml}$ of $5 \mathrm{mM}$ p-nitrophenyl$\beta$-D-galactopyranoside was added to experimental samples and incubated at $37^{\circ} \mathrm{C}$ for $1 \mathrm{~h}$. The reaction was stopped by $0.8 \mathrm{ml}$ of $0.1 \mathrm{M}$ soda solution. In the control the sample substrate is added after stopping 
the enzyme reaction. The absorbance was measured at $400 \mathrm{~nm}$ vs control samples. The activity of $\beta-\mathrm{Gal}$ urine was expressed in $\mu \mathrm{mol}$ p-nitrophenol/hr/mmol creatinine in urine [15]. The concentration of creatinine in urine was determined using reagent kits by Reagent (Ukraine).

For the statistical analysis, we used the Student's $t$-test, nonparametric (U-test) Mann-Whitney and Pearson's rank correlation test. Differences in values were considered statistically significant at $P<0.05$.

\section{Results and Discussion}

The results showed (Table 1) that the ACE activity in the blood of patients with CKD I-II stage (uncomplicated pyelonephritis) increased by $44 \%$ compared to conventionally healthy subjects (control group).

Changes in ACE activity stated an increase of markers of oxidative processes (serum TBARP level on 300 and $160 \%$ PCG), reduction of antiperoxide protection by reducing the content of $\mathrm{SH}$-groups by $18 \%$, TR by $29 \%$ and levels of arginine at an average by $60 \%$. The increase in ACE activity was accompanied by increased OS intensity against the background of antioxidant capacity of blood.

The correlative analysis confirmed the correlation between ACE activity and TBARP ( $r=0.362$, $P<0.05)$, SH-groups content $(r=-0.44, P<0.05)$, TPAe $(r=-0.507, P<0.05)$, OSI $(r=0.382$,
$P<0.05)$. So, the upregulation of ACE activity is accompanied by the intensification of oxidative process and decrease in antioxidant capacity of blood that promotes OS.

The results showed (Table 2) that the NAG activity in urine of patients with CKD I-II stage increased by $57 \%$ compared to that of conventionally healthy subjects (control group).

The levels of kidney damage markers $\beta$-Gal correlated with activity of ACE in urine $(r=0.365 P$ $<0.05$ ). The expediency of determining the levels of enzyme activity of lysosomal origin - total NAG and $\beta$-Gal in the urine of patients due to the fact that they are specific markers of renal tubular damage to the nephron, namely the epithelium of proximal tubules. As we know, lysosomes in infectious processes with overproduction of ROS were the first to respond, and the destruction of these organelles evidences for local inflammation. Increased activity of lysosomal enzymes, due to destruction of renal cell lysosomes, to some degree is considered to be markers of inflammation and OS markers [16]. The changes of activity lysosomal enzymes confirm the fact of kidney involvement in the disease process and the presence of inflammation in them.

As known, the increased activity of ACE promotes increase angiotensin II, activation of the renin-angiotensin-aldosterone system and endothelium reactions. In addition, angiotensin II stimulates the formation of ROS, which causes NO destruction

Ta ble 1. Indicators of oxidative stress and ACE activity in patients with chronic kidney disease stage I-II compared with conventionally healthy individuals $(M \pm m)$

\begin{tabular}{l|c|c|c}
\hline \multicolumn{1}{c}{ Indicators } & Control group, $n=30$ & $\begin{array}{r}\text { Patients with CKD } \\
\text { I-II stage, } n=32\end{array}$ & $\mathrm{p}$ \\
\hline & \multicolumn{2}{c}{ Blood serum } \\
ACE, $\mu \mathrm{kat} / / \mathrm{l}$, & $0.46 \pm 0.01$ & $0.66 \pm 0.04$ & $\mathrm{p}=0.02$ \\
TBARP, $\mu \mathrm{mol} / \mathrm{l}$ & $128.05 \pm 21.03$ & $385.03 \pm 37.04$ & $\mathrm{p}=0.02$ \\
PCG, $\mu \mathrm{mol} / \mathrm{l}$ & $1.13 \pm 0.12$ & $1.90 \pm 0.33$ & $\mathrm{p}=0.02$ \\
TR, $\mathrm{g} / \mathrm{l}$ & $5.21 \pm 1.02$ & $3.68 \pm 0.11$ & $\mathrm{p}=0.03$ \\
SH-groups, $\mathrm{mmol} / \mathrm{l}$ & $2.22 \pm 0.02$ & $1.83 \pm 0.02$ & $\mathrm{p}=0.03$ \\
CP, g/l & $0.22 \pm 0.01$ & $0.24 \pm 0.01$ & $\mathrm{p}=0.04$ \\
Arginine, $\mu \mathrm{mol} / \mathrm{l}$ & $125.21 \pm 28.48$ & $42.47 \pm 26.31$ & $\mathrm{p}=0.04$ \\
OSI, u.e. & $1.04 \pm 0.04$ & $3.40 \pm 1.30$ & $\mathrm{p}=0.02$ \\
& \multicolumn{1}{c}{ Red blood cells } & \\
TPA, $\mu \mathrm{kat} / \mathrm{g} \mathrm{Hb}$ & $7.62 \pm 0.34$ & $6.34 \pm 0.19$ & \\
TBARP, $\mu \mathrm{mol} / \mathrm{l}$ & $549.04 \pm 30.02$ & $606.03 \pm 44.04$ & \\
\hline
\end{tabular}


Ta ble 2. The activity of lysosomal enzymes in urine of patients with chronic kidney disease stage II conventionally healthy individuals $(M \pm m)$

\begin{tabular}{l|c|c|c}
\hline \multicolumn{1}{c|}{ Indicators } & $\begin{array}{c}\text { Control group, } \\
n=30\end{array}$ & $\begin{array}{c}\text { Patients with CKD } \\
\text { I-II stage, } n=32\end{array}$ & $\mathrm{p}$ \\
\hline & Urine \\
$\mathrm{NAG}, \mu \mathrm{mol} p$-nitrophenol $/ \mathrm{h} / \mathrm{mmol}$ creatinine & $11.64 \pm 0.72$ & $18.33 \pm 1.02$ & $\mathrm{p}=0.02$ \\
$\beta$-Gal, $\mu \mathrm{mol} \mathrm{p}$-nitrophenol $/ \mathrm{h} / \mathrm{mmol}$ creatinine & $9.58 \pm 0.68$ & $9.91 \pm 0.47$ & \\
\hline
\end{tabular}

$[1,6]$. NO is continuously synthesized in the endothelial cells of the renal vessels, mesangial cells and epithelial tubules, playing an important role in the regulation of renal blood flow, renal excretory function, tubuloglomerular balance $[1,17,18]$.

Some of these reactions occur in the interaction of NO with renin-angiotensin system, and NO deficiency is closely associated with its decrease in parenchymal renal lesions. Reduction of NO may be due to inhibition of renal cortical NOS, eNOS and limitation of arginine bioavailability, its synthesis in the kidney, renal tubular regeneration of arginine, its use of arginase or L-arginine: glycine amidinotransferase. NO is considered an antagonist of angioten$\sin$.

It is known that angiotensin-II affects the expression of nuclear transcription factor $\mathrm{kB}$, which controls the gene expression of cytokines, adhesion molecules, the expression of proinflammatory cytokines (TGF- $\beta$ ) increases under its influence and it stimulates the oxidation of low density lipoprotein by macrophages activation $[10,18,19]$.

In addition, it is known that NO prevents platelet aggregation and activation of a number of cells (particularly monocytes, which are transformed into macrophages containing lipids) and inhibits proliferation of smooth muscle cells, which are integral components of atherosclerotic vascular lesions and stimulants of ROS and OS. Inhibition of ACE promotes restoration of the balance between vasoactive systems: angiotensin II and NO [19, 20].

All these physiological responses at various stages of ROS formation promote intensification of oxidation process, but in case of a decrease - the antioxidant protection of blood and increase in the OS, it leads to kidney damage: to violation of hemodynamics, to hypertrophy of mesangial cells, to thickening of the basement membrane, to fibrosis interstices, to endothelial dysfunction and sclerosis of arterioles [1, 17].
A direct correlation between the increase in ACE activity in the serum of patients with chronic bacterial and inflammatory process in the kidneys, the OS intensity and the renal specific enzymes activity in urine.

Thus, the development of CKD stages I-II (uncomplicated pyelonephritis) in women of reproductive age is characterized by significant changes in oxidant/antioxidant balance of blood with increased activity of renal specific markers NAG, $\beta$-Gal in urine and ACE activity in serum. A statistically significant impairment of oxidant/antioxidant balance in the blood serum and in red blood cells (increased content of TBARP, PGC, and decrease in TR, SHgroups, TPAe), increase in ACE activity in the serum and enzyme activity of NAG and $\beta$-Gal in urine were characteristic of the patients with CKD stages I-II (uncomplicated pyelonephritis). Also the relationship between ACE activities in the serum of patients with CKD stages I-II with OS markers and between levels of ACE activity in serum levels and activity of renal specific enzymes in urine by the confirmed was data of correlative analysis.

\section{ІНТЕНСИВНІСТЬ ОКСИДАТИВНОГО \\ СТРЕСУ ТА АКТИВНІСТЬ АНГІОТЕНЗИНПЕРЕТВОРЮЮЧОГО ЕНЗИМУ В КРОВІ ПАЦІЕНТІВ З НЕУСКЛАДНЕНИМ ПІЄЛОНЕФРИТОМ}

\section{Л. В. Король, Л. Я. Мигаль, Н. М. Степанова}
ДУ «Інститут нефрології НАМН України», Київ; e-mail: lesyakorol@meta.ua

Мета даної роботи - вивчення взаємозв'язку маркерів оксидантного стресу (ОС) 3 активністю ангіотензинперетворюючого ензиму (АПЕ) в крові пацієнтів із неускладненим 
пієлонефритом. Досліджували активність АПЕ та маркерів ОС у 32 пацієнтів та у 30 практично здорових добровольців (жінки, вік 18-40 років). Вміст ТБК-активних продуктів, карбонільних груп протеїнів, церулоплазміну, трансферину, SH-груп, загальну пероксидазну активність еритроцитів визначали колориметричним методом. Розраховували індекс ОС. Для оцінки функціонального стану паренхіми нирок в сечі визначали активність канальцевих ензимів лізосом - загальної $\beta$ - $\mathrm{N}$-ацетилгексозамінідази та $\beta$-галактозидази. Проведено кореляційний аналіз між показниками активності АПЕ та ОС, a також показниками активності реноспецифічних ензимів. Встановлено підвищення активності АПЕ на тлі порушення про/антиоксидантного балансу. Кореляційний аналіз підтвердив наявність помірного зв'язку між активністю АПЕ та більшістю показників, що вивчалися. Отже, підвищення активності АПЕ, інтенсифікація оксидативних процесів, зниження антиоксидантного захисту сприяють розвитку системного та локального ОС, а також розвитку дисфункції канальцевого апарату нирок (за підвищенням активності реноспецифічних ензимів у сечі).

Кл юч ов і слова: оксидативний стрес, ангіотензинперетворюючий ензим, неускладнений пієлонефрит, $\beta$-N-ацетилгексозамінідаза, $\beta$-галактозидаза.

\section{ИНТЕНСИВНОСТЬ ОКСИДАТИВНОГО СТРЕССА И АКТИВНОСТЬ АНГИОТЕНЗИНПРЕВРАЩАЮЩЕГО ЭНЗИМА В КРОВИ ПАЦИЕНТОВ С НЕОСЛОЖНЕННЫМ ПИЕЛОНЕФРИТОМ}

\section{Л. В. Король, Л. А. Мигаль, Н. М.Степанова}

ГУ «Институт нефрологии НАМН Украины», Киев; e-mail: lesyakorol@meta.ua

Цель работы - изучение взаимосвязи маркеров оксидативного стресса (ОС) с активностью ангиотензинпревращающего энзима (АПЭ) в крови пациенток с неосложненным пиелонефритом. Исследовали активность АПЭ и маркеров ОС у 32 пациенток и 30 практически здоровых добровольцев (женщин, возраст - 1840 лет). Содержание ТБК-активных продуктов, карбонильных групп протеинов, церулоплаз- мина, трансферрина, SH-групп, общую пероксидазную активность эритроцитов определяли колориметрическим методом. Рассчитывали индекс ОС. Для оценки функционального состояния паренхимы почек в моче определяли активность канальцевых энзимов лизосом - общей $\beta$-N-ацетилгексозаминидазы и $\beta$-галактозидазы. Проводили корреляционный анализ между показателями активности АПЭ и ОС, а также показателями активности реноспецифических энзимов. Установлено увеличение активности АПЭ на фоне нарушения про/антиоксидантного баланса. Корреляционный анализ подтвердил наличие умеренной связи между активностью АПЭ и большинством изучаемых показателей. Таким образом, увеличение активности АПЭ, интенсификация оксидативных процессов, снижение антиоксидантной защиты способствовали развитию системного и локального ОС, а также развитию дисфункции канальцевого аппарата почек (по данным о повышении активности реноспецифических энзимов в моче).

К л ю ч е в ы е с л о в а: оксидативный стресс, ангиотензинпревращающий энзим, неосложненный пиелонефрит, $\beta-\mathrm{N}$-ацетилгексозаминидаза, $\beta$-галактозидаза.

\section{References}

1. Montezano AC, Dulak-Lis M, Tsiropoulou S, Harvey A, Briones AM, Touyz RM. Oxidative stress and human hypertension: vascular mechanisms, biomarkers, and novel therapies. Can J Cardiol. 2015; 31(5): 631-641.

2. Putri AY, Thaha M. Role of oxidative stress on chronic kidney disease progression. Acta Med Indones. 2014; 46(3): 244-252.

3. Touyz RM. Reactive oxygen species and angiotensin II signaling in vascular cells implications in cardiovascular disease. Braz $J$ Med Biol Res. 2004; 37(8): 1263-1273.

4. Montezano AC, Touyz RM. Oxidative stress, Noxs, and hypertension: experimental evidence and clinical controversies. Ann Med. 2012; 44(Suppl 1): S2-S16.

5. Arellano-Mendoza MG, Vargas-Robles $\mathrm{H}$, Del Valle-Mondragon L, Rios A, Escalante B. Prevention of renal injury and endothelial dysfunction by chronic L-arginine and antioxidant treatment. Ren Fail. 2011; 33(1): 4753. 
6. Agarwal R. Proinflammatory effects of oxidative stress in chronic kidney disease: role of additional angiotensin II blockade. Am J Physiol Renal Physiol. 2003; 284(4): F863-F869.

7. Bruder-Nascimento T, Chinnasamy P, RiascosBernal DF, Cau SB, Callera GE, Touyz RM, Tostes RC, Sibinga NE. Angiotensin II induces Fatl expression/activation and vascular smooth muscle cell migration via Nox1-dependent reactive oxygen species generation. $J$ Mol Cell Cardiol. 2014; 66: 18-26.

8. Kanzelmeyer NK, Pape L, ChobanyanJürgens K, Tsikas D, Hartmann H, Fuchs AJ, Vaske B, Das AM, Haubitz M, Jordan J, Lücke T. L-arginine/NO pathway is altered in children with haemolytic-uraemic syndrome (HUS). Oxid Med Cell Longev. 2014; 2014: 203512.

9. Lorin J, Zeller M, Guilland JC, Cottin Y, Vergely C, Rochette L. Arginine and nitric oxide synthase: regulatory mechanisms and cardiovascular aspects. Mol Nutr Food Res. 2014; 58(1): 101-116.

10. Cirillo P, Sautin YY, Kanellis J, Kang DH, Gesualdo L, Nakagawa T, Johnson RJ. Systemic inflammation, metabolic syndrome and progressive renal disease. Nephrol Dial Transplant. 2009; 24(5): 1384-1387.

11. Golikov PP, Nikolaeva NY. Express - method for determining the activity of angiotensinconverting enzyme in the whey of blood. Clin Lab Diag. 1998; 1: 11-13. (In Russian).

12. Lushchak VI, Bahniukova TV, Lushchak OV. Indices of oxidative stress. 1. TBA-reactive substances and carbonylproteins. Ukr Biokhim Zhurn. 2004; 76(3): 136-141. (In Ukrainian).

13. Pat. 102192 UA, ICP G01N 33/48 (2006.01). A Technique for integral evaluate of oxidantantioxidant balance in blood serum / Korol L.V., Myhal L.Ya. Publ. 10. 06. 2013, Bul. N 11. (In Ukrainian).
14. Farbiszewski R, Worowski K, Rzeczycki W. The application of a modified Sakaguchi's method for quantitative estimation of protein-bound arginine. Chem Analit. 1972; 17(1): 133-137.

15. Pat. 105521 UA, ICP G01N 33/493 (2006.01), A61P 13/12 (2006.01). A Technique for diagnostics of ischemic injury of the tubular nephrothelium in patients with phosphate nephrolithiasis / Chernenko VV, Myhal LYa, Nikulina HH, Chernenko DV, Zheltovska NI, Klius AL, Nehrei LM, Serbina IYe, Savchuk VYo. Publ. 25. 03. 2016, Bul. N 6. (In Ukrainian).

16. Mohkam M, Ghafari A. The Role of Urinary $\mathrm{N}$-acetyl-beta-glucosaminidase in Diagnosis of Kidney Diseases. J Ped Nephrology. 2015; 3(3): 84-91.

17. Pechman KR, De Miguel C, Lund H, Leonard EC, Basile DP, Mattson DL. Recovery from renal ischemia-reperfusion injury is associated with altered renal hemodynamics, blunted pressure natriuresis, and sodium-sensitive hypertension. Am J Physiol Regul Integr Comp Physiol. 2009; 297(5): R1358-R1363.

18. Sutariya B, Jhonsa D, Saraf MN. TGF- $\beta$ : the connecting link between nephropathy and fibrosis. Immunopharmacol Immunotoxicol. 2016; 38(1): 39-49.

19. Heymann F, Trautwein C, Tacke F. Monocytes and macrophages as cellular targets in liver fibrosis. Inflamm Allergy Drug Targets. 2009; 8(4): 307-318.

20. Tian N, Thrasher KD, Gundy PD, Hughson MD, Manning RD Jr. Antioxidant treatment prevents renal damage and dysfunction and reduces arterial pressure in salt-sensitive hypertension. Hypertension. 2005; 45(5): 934-939.

Received 16.11.2016 